\title{
PEMANFAATAN TRIMMING KULIT PIKEL SEBAGAI FLOKULAN MELALUI HIDROLISIS KOLAGEN MENGGUNAKAN BASA UNTUK PENJERNIHAN AIR
}

\section{UTILIZATION OF PICKLE SKIN TRIMMING WASTE AS FLOCCULANT THROUGH ALKALINE HYDROLYSIS OF COLLAGEN FOR WATER TREATMENT}

\author{
Sugihartono*, Sri Sutyasmi, Prayitno \\ Balai Besar Kulit, Karet, dan Plastik, Jl. Sokonandi No. 9, Yogyakarta 55166, Indonesia \\ * Penulis korespondensi. Telp.: (0274) 512929, 563939; Fax.: (0274) 563655 \\ E-mail: hsugihartono@ymail.com
}

Diterima: 13 Maret 2015 Direvisi: 18 Mei 2015 Disetujui: 25 Mei 2015

\begin{abstract}
Wastes in the form of skin derivatives from leather tanning industries remain serious problems if not managed properly and quickly, since they can cause environmental pollution. This research aimed at studying the influence of base type and concentration for the hydrolysis of trimmed collagen from pickled sheepskin to the yield and properties of gelatin, as well as the gelatin's potential as flocculant. The hydrolysis of trimmed collagen from pickled sheepskin was performed using $\mathrm{KOH}$ or $\mathrm{NaOH}$ solution, each with varied concentrations of 1, 2, 3, and 4\% $w / v$, for 16 hours. The extraction of the resulting gelatin was performed using water (2.5 water part: 1 waste part), at $70-80^{\circ} \mathrm{C}$, for 3 hours. The results show that the yield of gelatin from hydrolysis using $\mathrm{KOH}(16.50-28.60 \%)$ is lower than that using $\mathrm{NaOH}$ (23.68-34.42\%). The water and fat contents of the resulting gelatin were relatively similar, while the protein content from $\mathrm{KOH}$ treatment was higher than that from $\mathrm{NaOH}$ treatment. Hydrolysis with $\mathrm{KOH} 1 \%$ and $\mathrm{NaOH} 1 \%$ and $2 \%$ resulted in gelatin that can be used as flocculant. Hydrolysis with $\mathrm{NaOH} 2 \%$ was the best treatment to produce gelatin as flocculant.
\end{abstract}

Keywords: pickled sheepskin, trimming waste, hydrolysis, gelatin, flocculant.

\begin{abstract}
ABSTRAK
Limbah berupa kulit turunan dari industri penyamakan kulit masih menjadi masalah serius apabila tidak ditangani secara tepat dan cepat, karena dapat menimbulkan pencemaran lingkungan. Penelitian ini bertujuan untuk mempelajari pengaruh jenis dan konsentrasi basa untuk hidrolisis kolagen hasil trimming kulit domba pikel terhadap rendemen dan sifat gelatin serta kemampuannya sebagai flokulan. Hidrolisis kolagen hasil trimming kulit domba pikel dilakukan dengan menggunakan larutan $\mathrm{KOH}$ dan $\mathrm{NaOH}$, dengan konsentrasi berturut-turut 1, 2, 3, dan $4 \% \mathrm{~b} / \mathrm{v}$ selama 16 jam. Ekstraksi gelatin dilakukan dengan menggunakan air (2,5 bagian air : 1 bagian kulit) pada suhu $70-80{ }^{\circ} \mathrm{C}$, selama $3 \mathrm{jam}$. Hasil penelitian menunjukkan rendemen gelatin hasil hidrolisis menggunakan $\mathrm{KOH}$ adalah sebesar 16,5 - 28,60\%, lebih rendah dibandingkan dengan menggunakan $\mathrm{NaOH}$, yaitu sebesar 23,68 - 34,42\%. Kandungan air dan lemak gelatin relatif sama, sedangkan kandungan protein hasil perlakuan $\mathrm{KOH}$ lebih tinggi dari pada $\mathrm{NaOH}$. Sebaliknya, kandungan abu dan $\mathrm{pH}$ perlakuan $\mathrm{KOH}$ lebih rendah dibandingkan dengan perlakuan $\mathrm{NaOH}$. Hidrolisis dengan $\mathrm{KOH} 1 \%$ dan $\mathrm{NaOH} 1 \%$ serta $2 \%$ menghasilkan gelatin yang dapat berfungsi sebagai flokulan. Hidrolisis menggunakan $\mathrm{NaOH} 2 \%$ merupakan perlakuan terbaik untuk menghasilkan gelatin sebagai flokulan.
\end{abstract}

Kata kunci: kulit domba pikel, limbah trimming, hidrolisis, gelatin, flokulan.

\section{PENDAHULUAN}

Industri penyamakan kulit adalah industri yang mengolah kulit mentah (skin atau hide) menjadi kulit tersamak (leather). Pengolahan kulit mentah sebanyak 1 metrik ton, akan dihasilkan kulit samak sebesar $\pm 200 \mathrm{~kg}$, limbah kulit sebelum disamak $\pm 250 \mathrm{~kg}$, limbah kulit setelah disamak \pm $200 \mathrm{~kg}$, dan limbah cair $\pm 50.000 \mathrm{~kg}$ (Sundar et al. 2011). Vaskova et al. (2013) menyatakan bahwa hanya sekitar $20 \%$ dari kulit mentah yang dapat 
menjadi produk akhir, dan sisanya berupa limbah dalam berbagai bentuk yang setiap tahunnya mencapai jumlah jutaan ton. Limbah kulit turunan dari industri penyamakan kulit menjadi masalah utama, apabila tidak ditangani secara tepat dan cepat, bahkan dapat menimbulkan pencemaran lingkungan (Sugihartono, 2013).

Penggunaan bahan kimia seperti kapur, natrium sulfit, dan krom pada proses penyamakan kulit, memberi dampak dan kontribusi terhadap pembentukan limbah berbahaya yang mengancam kelestarian lingkungan hidup dan kesehatan manusia (Pawiroharsono, 2011). Limbah asal industri penyamakan kulit pada umumnya dalam bentuk padat, cair, dan gas. Semua jenis limbah tersebut dapat menimbulkan pencemaran air, tanah, dan udara. Pencemaran lingkungan limbah industri penyamakan kulit banyak dikeluhkan oleh masyarakat sekitar industri tersebut, seperti di Kabupaten Magetan. Keadaan ini juga disebabkan perhatian dari pemangku kepentingan yang masih belum optimal (Rosseto, 2013). Di India misalnya, air tanah di area sekitar industri penyamakan kulit sudah tidak layak digunakan sebagai air minum, karena air tersebut mengandung krom di atas ambang batas dan konsentrasi ionnya relatif tinggi (Brindha \& Elango, 2012).

Kulit hewan mengadung protein, lemak, air, kalori, kalsium, fosfor, besi, vitamin A, dan vitamin B1 (Widati dkk. 2012). Bagian terpenting dari komponen penyusun kulit adalah protein terutama kolagen. Hidrolisis parsial kolagen kulit, tulang, dan jaringan ikat hewan termasuk unggas dan ikan menggunakan asam, basa, atau secara enzimatis dihasilkan gelatin (GMIA, 2012). Gelatin merupakan biopolimer penting dan memiliki kegunaan cukup luas (Mariod \& Adam, 2013), antara lain untuk industri pangan, farmasi, fotografi, kosmetika, dan pembuatan gelatin teknis. Pada industri pangan, gelatin dapat digunakan sebagai bahan penjernih sari buah (fruit juices), cuka buah (vinegar), anggur dan bir (GMIA, 2012). Menurut Piazza et al. (2011), beberapa protein hewani dapat bertindak sebagai flokulan dengan aktivitas yang setara dengan flokulan an-ionik sintetis seperti poliakrilamid (PAM). Oleh karena itu gelatin trimming kulit domba pikel dimungkinkan dapat digunakan sebagai bahan pembantu untuk proses pengolahan/penjernihan air maupun air limbah.

Karakteristik gelatin antara lain ditentukan oleh bahan baku dan teknik produksi yang digunakan. Sebagai upaya untuk memperluas peng- gunaan atau pemanfaatan gelatin hewani, maka perlu dilakukan percobaan atau penelitian untuk mengetahui kemampuan gelatin sebagai flokulan. Penelitian ini bertujuan untuk mengetahui pengaruh jenis dan konsentrasi basa untuk hidrolisis kolagen terhadap rendemen, sifat gelatin, dan kemampuannya sebagai flokulan untuk penjernihan air. Dipilihnya basa untuk hidrolisis kolagen trimming kulit domba pikel, karena sifat gelatin seperti viskositas, bobot molekul, dan kekuatan gel hasil hidrolisis dengan larutan basa lebih baik daripada hidrolisis dengan larutan asam (Nurhalimah, 2010).

\section{BAHAN DAN METODE \\ Bahan Penelitian}

Bahan penelitian adalah limbah industri penyamakan kulit berupa trimming kulit domba pikel, kalium hiroksida $(\mathrm{KOH})$, natrium hidroksida $(\mathrm{NaOH})$, dan kaolin serta sejumlah bahan untuk uji karakterisasi gelatin. Trimming kulit domba pikel diperoleh dari PT. Budi Makmur Jaya Murni, Yogyakarta. Kalium hiroksida $(\mathrm{KOH})$, natrium hidroksida $(\mathrm{NaOH})$, dan kaolin yang digunakan adalah $\mathrm{KOH}, \mathrm{NaOH}$, dan kaolin teknis diperoleh dari UD. Sari, Yogyakarta.

\section{Peralatan Penelitian}

Peralatan yang digunakan pada penelitian ini terdiri atas timbangan digital merek Mettler Toledo AB204-S, penangas air (water bath) merek Memmert W 760 R, oven merek Memmert U 30 780682, pH meter merek Mettler Toledo Seven Easy N 315, seperangkat alat untuk uji Kjeldahl, gelas ukur, gelas piala, tabung reaksi, pipet ukur, labu ukur, magnetic stirrer, kompor listrik, ember plastik, saringan pemeras kelapa dilapisi kain saring, dan nampan plastik.

\section{Metode Penelitian}

Metode yang digunakan pada penelitian ini adalah metoda ekperimental skala laboratorium, menggunakan rancangan acak lengkap, dengan 2 faktor pengubah. Faktor pertama terdiri atas jenis basa dengan 2 taraf yaitu $\mathrm{KOH}$ dan $\mathrm{NaOH}$. Faktor kedua konsentrasi basa yang digunakan, dengan empat taraf berturut-turut 1, 2, 3, dan 4\% b/v. Percobaan diulang sebanyak 3 kali, sehingga dilakuan percobaan sebanyak 24 kali.

Kulit domba limbah trimming pikel dicuci dengan air mengalir selama 30 menit, sambil diaduk untuk membantu menghilangkan kotoran 
dan asam. Kulit tersebut kemudian ditiriskan dan dikeringanginkan. Setelah kering angin dikecilkan ukurannya agar memiliki ukuran $\pm 1,5 \mathrm{~cm} x$ 1,5 cm. Ditimbang sebanyak $100 \mathrm{~g}$ limbah kulit domba yang telah dikecilkan ukurannya, kemudian direndam dalam larutan basa dengan variasi berturut-turut $1,2,3$, dan $4 \% \mathrm{~b} / \mathrm{v}$ (5 bagian larutan basa : 1 bagian kulit) selama 16 jam. Kemudian sampel kulit dicuci sampai $\mathrm{pH}$ air cucian mencapai 6,5-7,5. Selanjutnya sampel kulit diekstrak/direbus menggunakan air (2,5 bagian air : 1 bagian kulit), pada suhu $70-80{ }^{\circ} \mathrm{C}$ selama 3 jam dan secara berkala dilakukan pengadukan. Filtrat yang terbentuk disaring dan dituang ke dalam nampan plastik, kemudian dijemur sampai kering. Gelatin kering selanjutnya dikemas dalam kantong plastik dan disimpan sampai dilakukan pengujian.

Uji gelatin meliputi rendemen, sifat fisik dan kimia serta uji kemampuannya sebagai flokulan. Uji sifat fisik dan kimia gelatin meliputi kadar air, abu, protein, lemak, karbohidrat, dan keasaman (pH). Uji rendemen, dan $\mathrm{pH}$ mengikuti cara Marzuki dkk. (2011), sedangkan uji kadar air, abu, protein, lemak, dan karbohidrat menurut prosedur Sudarmadji dkk. (1997).

Uji kemampuan flokulasi gelatin mengikuti cara Li et al. (2013) dimodifikasi sebagai berikut: mula-mula larutan gelatin 1\% disiapkan, dengan cara menimbang $0,3 \mathrm{~g}$ gelatin dan disuspensikan dalam $30 \mathrm{ml}$ aquades panas suhu $\pm 70^{\circ} \mathrm{C}$ dan diaduk menggunakan magnetic stirrer. Selanjutnya kaolin teknis ditimbang sebanyak $3 \mathrm{~g}$, dan dilarutkan dalam $300 \mathrm{ml}$ aquades, diaduk dan didiamkan selama 1 jam, endapan yang terbentuk dipisahkan. $10 \mathrm{ml}$ supernatan kaolin diambil, dimasukkan ke dalam tabung reaksi, kemudian ditambah suspensi gelatin $1 \%$ sebanyak $1 \mathrm{ml}$. Selanjutnya campuran sampel digojok agar suspensi gelatin tercampur merata dengan supernatan kaolin, kemudian didiamkan selama 24 jam. Pengamatan dilakukan secara visual, meliputi kejernihan air dan partikel melayang pada tabung reaksi.

\section{HASIL DAN PEMBAHASAN Rendemen}

Rata-rata 3 ulangan percobaan untuk penentuan rendemen gelatin hasil hidrolisis trimming kulit domba pikel menggunakan $\mathrm{KOH}$ dan $\mathrm{NaOH}$ dengan konsentrasi 1, 2, 3, dan $4 \% \mathrm{~b} / \mathrm{v}$ bervariasi dari $16,50-34,42 \%$. Kondisi trimming kulit domba pikel yang dihirolisis tersebut adalah kering udara dengan kadar air 44,91\%. Hasil uji rende- men gelatin disajikan pada Gambar 1. Gambar 1 menunjukkan bahwa rendemen gelatin trimming kulit domba pikel yang paling rendah diperoleh dari perlakuan basa $1 \%$, selanjutnya rendemen gelatin naik sampai pada perlakuan basa $3 \%$, dan akhirnya rendemen gelatin turun pada perlakuan basa $4 \%$. Penggunaan basa dimaksudkan untuk menghidrolisis serat kolagen kulit secara parsial menjadi gelatin, dan mampu mengubah serat kolagen triple helix menjadi rantai ganda, sedangkan hidrolisis menggunakan larutan asam mampu mengubah serat kolagen triple helix menjadi rantai tunggal (Peranginangin, 2007).

Biasanya kekuatan intrinsik flokulan meningkat seiring naiknya bobot molekul (Flocculants info, 2013). Untuk memperoleh gelatin dengan bobot molekul tinggi, maka hidrolisis digunakan basa. Disamping itu agar diperoleh hasil yang optimal diperlukan kesesuaian waktu hidrolisis, sumber gelatin, jenis, dan konsentrasi larutan basa, serta suhu dan lama ekstraksi. Pada penelitian ini penggunaan larutan $\mathrm{KOH} \mathrm{3 \%}$ dan $\mathrm{NaOH} 3 \%$ dengan lama hidrolisis 16 jam, masing-masing menghasilkan rendemen gelatin tertinggi yaitu $28,60 \%$ dan $34,42 \%$ dibandingkan dengan konsentrasi larutan basa lainnya (1, 2, dan 4\%).

Pada hidrolisis kolagen menggunakan konsentrasi larutan basa sebesar 4\% selama 16 jam, menghasilkan kondisi fisik kulit sebagian menjadi lebih lunak. Sebagai akibatnya adalah sebagian gelatin hilang/terikut air saat dilakukan pencucian pasca hidrolisis. Keadaan demikian menyebabkan rendemen gelatin turun pada perlakuan ektraksi kolagen trimming kulit domba pikel dengan konsentrasi larutan basa 4\% (Gambar 1).

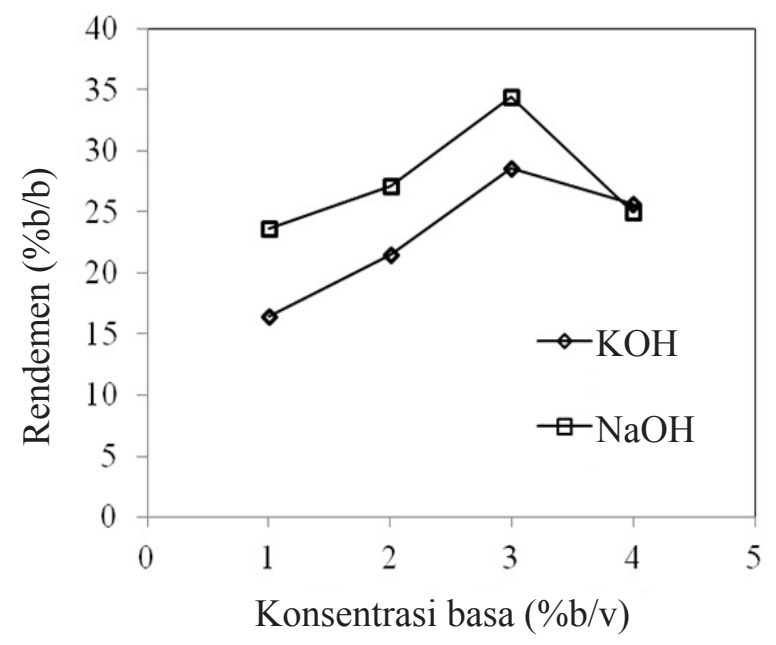

Gambar 1. Pengaruh konsentrasi basa (KOH dan $\mathrm{NaOH})$ terhadap rendemen gelatin. 
Secara keseluruhan, rendemen gelatin hasil perlakuan dengan larutan basa $\mathrm{KOH}$ adalah 16,50 - 28,60\%, dan $\mathrm{NaOH}$ adalah 23,68 - 34,42\%. Dengan demikian ditinjau dari segi rendemen, dapat dikemukakan bahwa proses pembuatan gelatin dari trimming kulit domba pikel menggunakan larutan basa $\mathrm{NaOH}$ lebih menguntungkan dari pada $\mathrm{KOH}$. Penggunaan larutan basa $\mathrm{NaOH}$ akan diperoleh rendemen lebih tinggi (34,42\%). Selisih rendemen antara perlakuan larutan basa $\mathrm{KOH}$ dan $\mathrm{NaOH}$ sebesar 5,82\%.

Menurut Nurhalimah (2010) rendemen gelatin kulit sapi dari industri penyamakan kulit dan dari rumah pemotongan sapi yang diolah menggunakan larutan basa sebesar 6,40\%$26,12 \%$. Said dkk. (2011) melaporkan bahwa rendemen gelatin kulit kambing yang dihidrolisis dengan larutan basa $\mathrm{Ca}(\mathrm{OH})_{2}$ sebesar 5,53-6,42\%. Menurut Amertaningtyas dkk. (2014), rendemen gelatin kulit kambing peranakan yang dihidrolisis dengan larutan kapur 5\% sebesar 12,82\%. Dengan demikian rendemen gelatin hasil penelitian lebih tinggi, apabila dibandingkan dengan hasil dari ketiga peneliti tersebut. Perbedaan tersebut antara lain disebabkan perbedaan bahan yang digunakan. Nurhalimah (2010) menggunakan limbah kulit split, Said dkk. (2011) menggunakan kulit kambing dengan basa $\mathrm{Ca}(\mathrm{OH})_{2}$, dan Amertaningtyas dkk. (2014), menggunakan kulit kambing peranakan dengan larutan kapur 5\%. Sedangkan pada penelitian ini digunakan trimming kulit domba pikel, dengan larutan basa $\mathrm{KOH}$ dan $\mathrm{NaOH}$. Kulit pikel adalah bagian kulit yang berupa korium (true skin) saja (Gumilar dkk., 2010), sedangkan bagian lainnya telah dihilangkan pada tahapan proses pengolahan sebelumnya. Korium merupakan kulit dengan kandungan terbesar protein kolagen, maka hidrolisis secara parsial akan dihasilkan gelatin dengan rendemen tinggi.

\section{Derajad Keasaman (pH)}

Derajad keasaman $(\mathrm{pH})$ suspensi gelatin sangat penting pada sifat kimia karena dapat mempengaruhi sifat gelatin untuk mementukan aplikasi berikutnya (Sompie et al, 2012). Hasil uji pH gelatin rata-rata dari 3 ulangan percobaan bervariasi dari 7,43-8,37 (Tabel 1). Derajad keasaman (pH) gelatin hasil perlakuan larutan basa $\mathrm{KOH}(7,43-$ 7,93) relatif lebih rendah apabila dibandingkan dengan hasil perlakuan larutan basa $\mathrm{NaOH}(7,9-$ $8,37)$. Hasil ini mirip dengan hasil penelitian yang dilakukan Said dkk. (2011) bahwa pH gelatin kulit kambing yang diolah menggunakan larutan basa $\mathrm{Ca}(\mathrm{OH})_{2}$ sebesar 7,23- 7,64.

Gelatin hasil penelitian ini belum semuanya memenuhi persyaratan $\mathrm{pH}$ gelatin tipe $\mathrm{B}$ untuk gelatin pangan, karena $\mathrm{pH}$-nya di luar kisaran 5-7,5 (GMIA, 2012). Hanya perlakuan dengan larutan basa $\mathrm{KOH} 1$ dan $4 \%$ yang memenuhi persyaratan $\mathrm{pH}$ gelatin tipe $\mathrm{B}$ untuk gelatin pangan. Sedangkan perlakuan menggunakan larutan basa $\mathrm{KOH} 2$ dan 3\%, serta $\mathrm{NaOH} 1-4 \%$ menghasilkan gelatin dengan $\mathrm{pH}$ relatif tinggi yaitu $>7,5$.

Tingginya $\mathrm{pH}$ gelatin dapat dijelaskan melalui mekanisme reaksi sebagai berikut, mulamula terjadi reaksi antara sisa asam sulfat pada kulit pikel dengan basa membentuk garam dan air. Reaksi kimia yang terjadi adalah:

$\mathrm{H}_{2} \mathrm{SO}_{4}+2 \mathrm{KOH} \rightarrow \mathrm{K}_{2} \mathrm{SO}_{4}+2 \mathrm{H}_{2} \mathrm{O}$

$\mathrm{H}_{2} \mathrm{SO}_{4}+2 \mathrm{NaOH} \rightarrow \mathrm{Na}_{2} \mathrm{SO}_{4}+2 \mathrm{H}_{2} \mathrm{O}$

Pasca reaksi dengan sisa asam, maka basa akan menghidrolisis kolagen, pada saat kolagen mengembang, sisa basa sebagian terperangkap sehingga sulit keluar pada saat pencucian. Sebagai akibatnya adalah $\mathrm{pH}$ gelatin menjadi tinggi karena basa yang terperangkap dalam bahan terikut pada saat ekstraksi. Agar $\mathrm{pH}$ gelatin $<7,5$ maka setelah hidrolisis sampel perlu direndam dalam air agar basa yang terperangkap dalam bahan dapat keluar bersama air cucian.

\section{Kadar Air, Abu, Protein, Lemak, Dan Karbo- hidrat}

Hasil uji proksimat (air, abu, protein, lemak dan karbohidrat) rata-rata dari 3 ulangan percobaan disajikan pada Tabel 1. Kadar air gelatin bervariasi dari $11,58-12,72 \%$, abu $1,75-4,94 \%$, protein 79,31-84,64\%, lemak 0,14-0,23\%, dan karbohidrat 0,63 - 3,38\%. Menurut Gomez-Guillen et al. (2009) di dalam Sompie et al. (2012), bahwa sifat fisik dan kimia gelatin sangat dipengaruhi oleh jenis bahan baku, umur hewan, tipe kolagen, metode pembuatan, tipe jaringan, spesies, karakteristik kolagen, dan proses perlakuan.

Kadar air tertinggi gelatin dijumpai pada penggunaan larutan $\mathrm{NaOH} 1 \%$ sebesar $12,72 \%$, dan terendah pada $\mathrm{NaOH} 3 \%$ sebesar 11, 58\%. Kadar air gelatin menurut Standar Mutu Gelatin (SNI 06-3735-1995) maksimum 16\%. Hal ini berarti kadar air gelatin hasil penelitian memenuhi persyaratan SNI 06-3735-1995 tentang mutu gelatin. Secara keseluruhan gelatin yang disiapkan dengan larutan $\mathrm{KOH}$ memiliki kadar air cenderung lebih tinggi apabila dibandingkan dengan kadar 
Tabel 1. Hasil uji pH dan proksimat (air, abu, protein, lemak dan karbohidrat) gelatin.

\begin{tabular}{cccccccc}
\hline $\begin{array}{c}\text { Perlakuan } \\
\text { basa }\end{array}$ & $\begin{array}{c}\text { Konsentrasi, } \\
\% \mathrm{~b} / \mathrm{v}\end{array}$ & $\mathrm{pH}$ & $\begin{array}{c}\text { Air, \% } \\
\mathrm{b} / \mathrm{bb}\end{array}$ & $\begin{array}{c}\mathrm{Abu}, \\
\% \mathrm{~b} / \mathrm{bb}\end{array}$ & $\begin{array}{c}\text { Protein, } \\
\% \mathrm{~b} / \mathrm{bb}\end{array}$ & $\begin{array}{c}\text { Lemak, } \\
\% \mathrm{~b} / \mathrm{bb}\end{array}$ & $\begin{array}{c}\text { Karbohidrat, } \\
\% \mathrm{~b} / \mathrm{bb}\end{array}$ \\
\hline $\mathrm{KOH}$ & 1 & 7,43 & 12,37 & 2,21 & 84,64 & 0,15 & 0,63 \\
& 2 & 7,70 & 12,09 & 1,75 & 84,03 & 0,22 & 0,93 \\
& 3 & 7,93 & 12,21 & 3,57 & 82,36 & 0,21 & 1,22 \\
$\mathrm{NaOH}$ & 4 & 7,50 & 12,17 & 2.72 & 82,99 & 0.18 & 1,81 \\
& 1 & 8,03 & 12,72 & 2,17 & 83,29 & 0,20 & 1,63 \\
& 2 & 7,90 & 11,79 & 2,15 & 83,96 & 0,14 & 1,97 \\
& 3 & 8,23 & 11,58 & 3,23 & 81,57 & 0,23 & 3,37 \\
\hline
\end{tabular}

air gelatin hasil ekstraksi dengan larutan $\mathrm{NaOH}$. Amertaningtyas dkk. (2014), melaporkan bahwa kadar air gelatin kulit kambing peranakan yang dicuring dengan larutan kapur 5\% sebesar 9,29\%. Dengan demikian kadar air gelatin hasil ekstraksi trimming pikel kulit domba, walaupun memenuhi standar mutu gelatin sesuai SNI 06-3735-1995 namun masih lebih tinggi dari pada yang dilaporkan oleh Amertaningtyas et al. (2014).

Kadar abu tertinggi terdapat pada hasil perlakuan dengan larutan $\mathrm{NaOH} 4 \%$ sebesar 4,94\% dan terendah diperoleh dari hasil perlakuan dengan larutan $\mathrm{KOH} 2 \%$ sebesar 1,75\%. Kadar abu gelatin hasil perlakuan larutan $\mathrm{KOH}$ relatif lebih rendah apabila dibandingkan dengan perlakuan larutan $\mathrm{NaOH}$. SNI 06-3735-1995 mensyaratkan bahwa kadar abu gelatin maksimum 3,25\%. Hal ini berarti bahwa gelatin hasil penelitian belum kesemuanya memenuhi syarat SNI 06-3735-1995. Kadar abu gelatin hasil perlakuan dengan larutan $\mathrm{NaOH} 4 \%$ tidak memenuhi syarat SNI 06-37351995, karena nilainya melebihi persyaratan yang ditetapkan 4,94\%. Hal ini disebabkan proses pengeringan gelatin dilakukan dengan cara penjemuran di udara terbuka, sehingga memungkinkan debu-debu atau komponen mineral terhembus oleh angin masuk kedalam gelatin dan terbawa hingga proses pengabuan.

Kadar protein terendah terdapat pada hasil perlakuan dengan larutan $\mathrm{NaOH} 4 \%$ sebesar $79,31 \%$ dan tertinggi diperoleh dari hasil perlakuan dengan larutan $\mathrm{KOH} 1 \%$ sebesar 84,64\%. Secara keseluruhan kadar protein gelatin hasil perlakuan dengan larutan $\mathrm{KOH}$ relatif lebih tinggi dari pada perlakuan dengan larutan $\mathrm{NaOH}$. Kadar protein tersebut lebih tinggi dari pada yang dilaporkan oleh Amertaningtyas dkk. (2014), bahwa kadar protein gelatin kulit kambing peranakan yang di-curing dengan larutan kapur 5\% adalah $73,58 \%$. Tabel 1 menunjukkan bahwa gelatin hasil perlakuan dengan konsentrasi larutan basa memiliki kadar protein relatif tinggi kemudian semakin turun seiring dengan kenaikan konsentrasi larutan basa baik $\mathrm{KOH}$ maupun $\mathrm{NaOH}$. Pada konsentrasi larutan basa 1 dan 2\% masih menghasilkan gelatin dengan kadar potein relatif lebih tinggi apabila dibandingkan dengan perlakuan konsentrasi laru$\tan$ basa 3\% dan 4\%. Namun demikian rendemen gelatin hasil perlakuan dengan larutan basa 3\% lebih tinggi apabila dibandingkan dengan perlakuan dengan larutan basa lainnya. Kandungan protein gelatin hasil perlakuan dengan larutan basa $2 \%$ lebih tinggi daripada perlakuan dengan larutan basa 3\%. Oleh karena itu perlakuan penggunaan larutan basa terbaik untuk pengolahan gelatin dipilih sesuai dengan tujuan penggunaan gelatin.

Brown et al. (2012) menyatakan bahwa bahan untuk penghilangan bulu kulit sapi pada pretanning berpengaruh pada sturktur kolagen kulit sapi. Hasil analisis kandungan protein yang dihitung berdasarkan nitrogen total gelatin kulit sapi berbeda sangat nyata diantara perlakuan penghilangan bulu kulit sapi. Protein gelatin hasil perlakuan secara oksidasi, berbeda sangat nyata dengan protein gelatin hasil perlakuan sulfit dan protein gelatin komersial. Kandungan protein gelatin tipe I yang bulunya dihilangkan secara oksidasi adalah sebesar 92,07 \%, sedangkan penggunaan sulfit dihasilkan protein gelatin $84,52 \%$. Keadaan demikian berarti kandungan protein gelatin hasil penelitian menggunakan larutan $\mathrm{KOH} 1 \%$ dan $\mathrm{NaOH}$ $2 \%$ mirip dengan kandungan protein gelatin yang dilaporkan oleh Brown et al. (2012) sebagaimana diuraikan di atas. 
Kadar lemak tertinggi dijumpai pada perlakuan dengan larutan $\mathrm{NaOH} 3 \%$ dan 4\% dengan hasil sama yaitu sebesar $0,23 \%$, sedang kandungan lemak terendah juga diperoleh dari hasil perlakuan dengan larutan $\mathrm{NaOH} 2 \%$ yaitu sebesar $0,14 \%$. Kadar lemak tersebut lebih rendah dari pada yang dilaporkan oleh Amertaningtyas et al. (2014), bahwa kadar lemak gelatin kulit kambing peranakan yang dicuring dengan larutan kapur $5 \%$ sebesar $1,7 \%$. Kadar lemak gelatin hasil penelitian dari trimming kulit domba pikel relatif rendah dan antar perlakuan konsentrasi larutan basa tidak menunjukkan variasi yang tinggi. Kadar lemak gelatin tidak dipersyaratkan dalam SNI 06-3735-1995, namun demikian dapat dilaporkan bahwa gelatin komersial dari kulit sapi memiliki kandungan lemak 0,23\% (Pranoto et al., 2011). Dengan demikian semua gelatin hasil penelitian memenuhi standar seperti halnya gelatin kulit sapi komersial.

Kadar karbohidrat tertinggi dijumpai pada perlakuan dengan larutan $\mathrm{NaOH} 4 \%$ sebesar $3,38 \%$ dan terendah diperoleh dari hasil perlakuan dengan larutan $\mathrm{KOH} 1 \%$ sebesar $0,63 \%$. Penentuan jumlah karbohidrat gelatin berdasarkan pada perhitungan, sehingga dimungkinan terdapat bahan lain seperti vitamin dan asam-asam organik yang dihitung sebagai karbohidart. Seperti halnya lemak, kadar karbohidrat juga tidak dipersyaratkan dalam SNI 06-3735-1995. Keberadaan karbohidrat dalam kulit hewan sangat kecil, dan belum diketahui pengaruhnya terhadap sifat fungsional gelatin. Sebenarnya sifat fungional gelatin terkait dengan karakteristik kimianya, seperti kekuatan gel, viskositas, pengaturan perilaku dan titik leleh gelatin tergantung pada distribusi bobot molekul dan komposisi asam aminonya (Mariod \& Adam, 2013).

\section{Uji Kemampuan Flokulasi}

Hasil uji kemampuan flokulasi gelatin menunjukkan bahwa penambahan suspensi gelatin 1\% sebanyak $1 \mathrm{ml}$ ke dalam $10 \mathrm{ml}$ suspensi kaolin $1 \%$, dan didiamkan selama 24 jam telah mampu mengendapkan suspensi kaolin tersebut. Dengan kata lain penambahan $1 \mathrm{~g}$ gelatin ke dalam 1000 $\mathrm{ml}$ larutan suspensi kaolin 1\% telah mampu mengendapkan suspensi kaolin tersebut dalam waktu 24 jam. Pengendapan sempurna dijumpai pada gela-

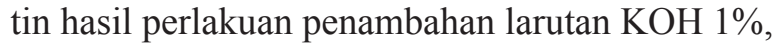
dan $\mathrm{NaOH} 1$ serta $2 \%$. Pengendapan yang belum sempurna dari suspensi kaolin $1 \%$ berturut-turut dari zona bening tinggi ke rendah adalah suspensi gelatin hasil perlakuan dengan larutan $\mathrm{KOH} 2 \%$, $\mathrm{NaOH} 3 \%, \mathrm{KOH} 3 \%$, dan terendah adalah suspensi gelatin $1 \%$ hasil perlakuan dengan larutan $\mathrm{KOH} 4 \%$ dan $\mathrm{NaOH} 4 \%$. Perlakuan flokulasi kontrol (tanpa ditambah suspensi gelatin 1\%), terjadi pengendapan dan pembentukan cairan bening, namun masih terlihat keberadaan partikel kaolin 1\% yang melayang-layang.

Perlakuan dengan larutan $\mathrm{KOH} 1 \%$ dan $\mathrm{NaOH} 1$ dan 2\% memiliki kemampuan flokulasi lebih tinggi dibandingkan dengan gelatin hasil perlakuan larutan basa lainnya. Keadaan ini diperkuat dengan hasil uji protein bahwa perlakuan dengan larutan basa 1 dan $2 \%$ menghasilkan protein gelatin lebih tinggi apabila dibandingkan dengan larutan basa konsentrasi 3 dan 4\%. Karakteristik gelatin seperti viskositas, bobot molekul dan kekuatan gel yang diperoleh dari ekstraksi dengan larutan basa lebih baik dari pada ekstraksi gelatin dengan larutan asam (Nurhalimah, 2010). Biasanya kekuatan intrinsik flokulan naik seiring dengan kenaikan bobot molekul polimer (Flocculants Info, 2013).

Perlakuan dengan larutan $\mathrm{KOH} 1 \%$ dan $\mathrm{NaOH} 1$ dan $2 \%$ menghasilkan gelatin berturutturut sebesar16,5\%, 23,68\%, dan 26,84\%. Dengan demikian dapat dikemukakan bahwa perlakuan terbaik hidrolisis kolagen untuk menghasilkan gelatin sebagai flokulan adalah perlakuan dengan konsentrasi larutan $\mathrm{NaOH} 2 \%$, dengan rendemen gelatin paling tinggi meskipun kemampuan flokulasinya sama dengan penggunaan larutan $\mathrm{KOH}$ $1 \%$ dan $\mathrm{NaOH} 1 \%$.

\section{KESIMPULAN}

Jenis dan konsentrasi larutan basa $(\mathrm{KOH}$ dan $\mathrm{NaOH}$ ) untuk hidrolisis trimming kulit domba pikel berpengaruh terhadap rendemen, $\mathrm{pH}$, kandungan protein, dan air gelatin. Rendemen gelatin naik sampai konsentrasi 3\%, kemudian turun pada konsentrasi larutan basa 4\%. Hidrolisis menggunakan larutan $\mathrm{KOH}$ menghasilkan gelatin dengan rendemen, $\mathrm{pH}$, dan abu relatif lebih rendah, namun protein relatif lebih tinggi apabila dibandingkan dengan perlakuan larutan $\mathrm{NaOH}$. Perlakuan terbaik untuk digunakan sebagai flokulan adalah hidrolisis dengan larutan $\mathrm{NaOH} 2 \%$, pada kondisi demikian dapat dihasilkan gelatin sebesar 26,84\%, dan mampu menjernihkan suspensi kaolin dalam waktu 24 jam. 


\section{UCAPAN TERIMA KASIH}

Penulis mengucapkan terima kasih kepada PT. Budi Makmur Jaya Murni, Yogyakarta dan kepada Ibu Asri Dwi Pratiwi, A.Md, atas partisipasinya dalam penyediaan bahan penelitian dan preparasi sampel untuk penelitian.

\section{DAFTAR PUSTAKA}

Amertaningtyas, D., Thohari, I., Purwadi, P., Radiati, L. E., Rosyidi, D., \& Jaya, F. (2014). Pengaruh konsentrasi larutan kapur sebagai curing terhadap kualitas fisiko-kimia dan organoleptik gelatin kulit kambing Peranakan Ettawah (PE). Jurnal IlmuIlmu Peternakan, 24(2), 1-7.

Brown, E., Latona, R., Taylor, M., \& Garcia, R. (2012). Effects of pretanning processes on bovine hide collagen structure. Journal of the American Leather Chemists Association, 107(1), 1-7.

Flocculants Info. (2013). To Inform, educate and instruct by example. www.flocculant.info, diakses 26 Maret 2014.

Brindha, K., \& Elango, L. (2012). Impact of tanning industries on groundwater quality near a metropolitan city in India. Water Resources Management, 26(6), 1747-1761.

DSN (Dewan Standarisasi Nasional). (1995). Standar Nasional Indonesia SNI 06-3735-1995. Mutu dan cara uji gelatin. Jakarta, Indonesia: DSN.

GMIA (Gelatin Manufacturers Institute of America). (2012). Gelatin Handbook. Hill street, Woburn, Massachusetts, 01801.

Gumilar, J., Putranto, W. S., \& Wulandari, E. (2010). Pengaruh penggunaan asam sulfat $\left(\mathrm{H}_{2} \mathrm{SO}_{4}\right)$ dan asam formiat $(\mathrm{HCOOH})$ pada proses pikel terhadap kualitas kulit jadi (leather) domba Garut. Jurnal Ilmu Ternak, 10(1), 1-6.

Li, R., Liao, X., He, Q., \& Shi, B. (2013). A Collagenbased flocculant prepared from solid leather waste. In Proceding XXXII Congres of UILTCS. Istambul, Turkey: IULTCS.

Mariod, A. A. \& Adam, H. F. (2013). Review: Gelatin, source, extraction, and industrial application. Acta Scientiarum Polonorum. Technologia Alimentaria. 12(2), 135-147.

Marzuki, A., Pakki, E., \& Zulfikar, F. (2011). Ekstraksi dan penggunaan gelatin dari limbah tulang ikan bandeng (Chanos chanos Forskal) sebagai emulgator dalam formulasi sediaan emulsi. Majalah Farmasi dan Farmakologi, 15(2), 63-68.

Nurhalimah, E. (2010). Comparison of gelatine extraction process of bovine hide split by acid and base process (Skripsi). Institut Pertanian Bogor, Indonesia.
Pawiroharsono, S. (2011). Penerapan enzim untuk penyamakan kulit ramah lingkungan. Jurnal Teknologi Lingkungan, 9(1), 51-58.

Peranginangin, R. (2007). Teknologi ekstraksi gelatin secara asam dari kulit ikan sebagai bahan pangan dan farmasi. Dalam Prosiding simposium riset kelautan dan perikanan. Jakarta, Indonesia: LIPI.

Piazza, G. J., Mc Aloon, A. J., \& Garcia, R. A. (2011). A renewable flocculant from a poultry slaughterhouse waste and preliminary estimate of production costs. Resources, Conservation and Recycling, 55(9), 842-848.

Pranoto, Y., Marseno, D. W., \& Rahmawati, H. (2011). Characteristics of gelatins extracted from fresh and sun-dried seawater fish skins in Indonesia. International Food Research Journal, 18(4), 1335-1341.

Rosseto, W. R. (2013). Kebijakan pemerintah dalam mengatasi pencemaran limbah industri penyamakan kulit (Studi pada Badan Lingkungan Hidup dan Dinas Perindustrian \& Perdagangan Kabupaten Magetan). Jurnal Administrasi Publik, 1(7).

Said, M. I., Triatmojo, S., Erwanto, Y., \& Fudholi, A. (2011). Karakteristik gelatin kulit kambing yang diproduksi melalui proses asam dan basa. Jurnal Agritech, 31(3), 190-200.

Sompie, M., Triatmojo, S., Pertiwiningrum, A., \& Prananto, Y. (2012). Pengaruh umur potong dan konsentrasi larutan asam asetat terhadap sifat fisik dan kimia gelatin kulit babi. Sains Peternakan, 10, 15-22.

Sudarmadji, S., Haryono, B., \& Suhardi. (1997). .Prosedur analisa untuk bahan makanan dan pertanian. 4ed. Yogyakarta, Indonesia: Liberty.

Sugihartono, S. (2013). Pemanfaatan limbah penyamakan kulit menjadi gelatin untuk industri pangan. Jurnal Riset Teknologi Industri, 7(14), 87-99.

Sundar, V. J., Gnanamani, A., Muralidharan, C., Chandrababu, N. K., \& Mandal, A. B. (2011). Recovery and utilization of proteinous wastes of leather making: a review. Reviews in Environmental Science and Biotechnology, 10(2), 151-163.

Vaskova, H., Kolomazník, K., \& Vasek, V. (2013). Hydrolysis process of collagen protein from tannery waste materials for production of biostimulator and its mathematical model. International Journal of Mathematical Models and Methods in Applied Sciences, 5(7), 568-575.

Widati, A. S., Mustakim, M., \& Indriana, S. (2012). The effect of liming time on protein content, moisture, calcium, volume expansion and organoleptic quality of rambak. Jurnal Ilmu dan Teknologi Hasil Ternak, 2(1), 47-56. 
